\title{
Demographic Variables Influence on Household Participation on Small Savings in Indigenous Voluntary Organisations at Wolaita Sodo Town, Ethiopia
}

\author{
Dr. G. Sudhakar \\ Management Professor (Visiting) \\ Hyderabad \\ Telangana
}

\begin{abstract}
Savings and credit scheme aims at poverty alleviation to the poor and low income families. Equb, Mahiber and Eddir are very old traditional institutions and indigenous voluntary organisations in Ethiopia that maintain their importance up to till today. Informal financial institutions such as Rotating Savings and Credit Associations (ROSCAs) and their participants have received growing attention over the last two decades. They become even more and more relevant as time goes on and as the economy becomes stronger. This study assessed the influence of demographic factors of saving behaviour of the household members of Wolaita Sodo town, Ethiopia. The study has been conducted on the basis of the primary data collected through structured questionnaire. The data was collected from 385 household who participate in the small savings survey at 95\% confidence level. Judgemental sampling technique was used to choose the respondents. Questionnaire was prepared using five point Likert scale to measure the response on continuous scale. Descriptive and inferential statistics were used as data analysis tool. The analysis of variance of demographic variables on household participation on small savings showed that gender, marital status and educational status were statistically insignificant to predict the household participation on small savings whereas Age, expenditure factor, level of income and family size were statistically significant to predict household participation on small savings.
\end{abstract}

Keywords: Financial Institutions, Interest Rate, Behaviour, Credit, Mobilization, Savings

DOI: $10.7176 / \mathrm{EJBM} / 11-1-08$

\section{BACKGROUND OF THE STUDY}

The formal financial institutions have extensive infrastructures and system, strong management capacity, access to funds, yet they are further removed from rural investors making obtaining adequate information and enforcing contracts imperfect and costly. In contrast, informal financial institutions which operate close to rural borrowers possess enforcement mechanisms, have acceptable credit programmers, low cost of transaction, cheap outreach and good information about borrowers, but they do not provide enough credit to investors, neither have they linked borrowers to the mainstream financial sector as a result of institutional factors.

In low-income communities, most people prefer to save their cash in undisclosed places like roof, pot, wall, underground, and/or under their bed. This encompasses risk of theft, damaging by termites and loss in case of fire. Savings and credit scheme aims at poverty alleviation to the poor and low income families. Small farmers are poor in general especially in African and Asian because of their limited access to deposit and credit; high interest rates charged by non-institutional lenders are important factors that governments, and donors to promote alternative rural saving, and credit institutions (cooperatives) in developing countries. The distribution of credit by government owned or sponsored rural financial institutions have frequently been skewed in favor of the wealthier and more influential farmers.

In Ethiopia, there are a number of indigenous voluntary associations which existed in a variety of forms in different cultural, religious and socio-economic contexts. The first organizations in Ethiopia were self-help systems. They existed in the country for centuries before they started to take shape and developed in to some sort of well-established structures (Alema, 2008). Among the well-known indigenous voluntary associations in Ethiopia includes, Eddir, Equb and Mahiber. Informal financial institutions such as Rotating Savings and Credit Associations (ROSCAs) and their participants have received growing attention over the last two decades. Eddir is a burial association established based on the mutual agreement of community members to collaborate whenever an adverse situation occur in any member of the family. It has different functions and benefits to its members. For instance, it provides financial, material, labor and emotional support at the time of mourning. Furthermore, some of them have been involving in provision of different social services such as schools and health services, and some are engaged in income generating activities such as consumer goods shop, renting halls and equipment which are mainly found in urban centers (Alema, 2008). Equb offers a savings mechanism for households in Ethiopia and it is a high contributing factor for economic sustainability of households. Unlike many other traditional institutions that have vanished or diminished with the introduction of new laws and technology, Equb, Mahiber and Eddir are flourishing and becoming the hub of the financial industry in many 
aspects.

Cooperatives are about people working together to meet their common needs and aspirations of its members, sharing ownership and making decisions democratically. They are a major force in achieving Socio-economic development among its members in urban and rural areas in Ethiopia. Cooperatives in their various forms (modern and traditional) promote the fullest possible participation in economic and social development of people, including women, youth, older persons and persons with disabilities are becoming a major factor of economic and social development and contribute to the eradication of poverty (Destahun, 2008).

Household save for a variety of reasons such as liquidity constraint or life cycle savings. In developing countries, savings are important determinants of household welfare. Without savings, households have few other mechanisms to smooth out unexpected variations in their income, and so, shocks may create some problems of human capital accumulation at early ages (Attanasio, 1998). In particular, Ethiopia, like other developing countries, is prone to adverse shocks such as bad weather events, pest and downward in the price of agricultural output relative to the cost of agricultural inputs. Therefore, it is relevant for rural households to consider saving as possible protection against the occurrence of such shock. Additional to its micro-level effects, household deposits make capital available for investment and as such contribute to macro-economic growth (Kifle, 2012).

The small and marginal farmers and rural artisans find it difficult to make investment because they do not have sufficient funds of their own for this purpose (Kifle, 2012). In low or negatives savings, investment financed partly by government borrowings and grants but this would significantly increase the country's debt burden and would not be a solution in the long run. Evidences indicate that over-emphasis on easy credit policy and under attention to savings promotion has tended to weaken the capacity of the rural poor to mobilize and manage their own resources (Teka, 2008).

\section{STATEMENT OF THE PROBLEM}

Human beings have started living a communal life, they have created different social, religious and political institutions that serve the interest of their community. These institutions serve the society in different ways including maintaining its identity, history and cultures and passing its values, moral understandings and customs from generation to generation. The traditional institutions do not operate in a vacuum. There are well-established values, principles, customs and very strict ritual practices that govern the very existence of the traditional institutions. Furthermore, the traditional institutions are bound to observe and respect these guiding values and principles and laws to be acceptable and valid institutions of the society

In several African societies where the state plays only a limited role in organizing public life, the activities of indigenous or voluntary associations constitute an important aspect of people's life. These self-help voluntary associations are the African's own response to the stresses and difficulties they face and became crucial aspects of the coping mechanisms and adaptive strategies (Salole, 1991) As saving gap is one of the serious problems confronting many developing countries, these associations provide an alternative saving mechanisms through domestic saving thereby help to reduce the luck of finance for investment. Moreover, they play a crucial role for sustainable development, especially at local level, by mobilizing resources and regulating their utilization with an outlook of maintaining a long-term base for productive activities (Mowo et al, 2011).

Members' participation through savings and loan-taking is the determinant factor for the sustainable growth of cooperatives. In Ethiopia, however, $78.7 \%$ of the members became a member in cooperatives forcefully by cooperative promoters. As a result, the members' were not aware of the benefits, duties, and rights they have in the cooperative societies; largely the participation of members was weak.

According to Ethiopian Federal Cooperative Agency (2014), poor savings culture of members, nonexistence of a clear cooperative law and policy package, lack of adequate capacity to lead and manage cooperatives, lack of finance are the main challenges of Ethiopian cooperatives. Most of the researches held in Southern Ethiopia found the members' savings participation were poor. However, reasons for the members' poor participation were not adequately investigated. Therefore, this study assessed the determinants level of saving behaviour of the household members of Wolaita Sodo town, Ethiopia.

\section{RESEARCH OBJECTIVE}

To assess the influence of demographic variables of household participation on small savings in indigenous voluntary organisations at Wolaita Sodo town of Ethiopia.

\section{SCOPE OF THE STUDY}

The scope of this study is limited to the factors that affect the household participation in small savings that operate in Wolaita Sodo town only. Conceptually, this study will give insight into improvements of saving behaviour of the household like improving motive to receive credit, saving mobilization, income, expenditure, educational status, and interest rate. 


\section{SIGNIFICANCE OF THE STUDY}

Rural saving and credit cooperative society can therefore develop more appropriate marketing strategies to tap and penetrate non savers in Ethiopia. By doing this, the profitability and competitiveness of rural savings and credit cooperative societies can be improved. The study will help to undertake the appropriate recommendation on the household small savings habits under the study depending on the output of the research. It provides reliable information about household participation behaviour on small savings which will contribute to sustainable economic development.

\section{LITERATURE REVIEW}

Ogaki et al. (1995) conducted research and proved that people save more of their income if rate of interest is high. They concluded that interest rate and savings are positively related. They reported that savings depends on rate of interest, in terms of rate of return at elevated levels of income.

The results of the study conducted by Muradoglu and Taskin (1996) indicated that demographic variables such as age groups, birth rates, dependency ratio and financial variables such as interest rates, inflation rates, available financial instruments and initial wealth levels affected the decision of household savings significantly.

Fernandez et al. (2009) investigate the determinants of savings from eight countries in Europe. In accordance to the life-cycle economic approach that people tend to save more as they reach retirement, they have found that age has a positive impact on savings. Furthermore, the results show that the probability to save is rising with age, but at a progressively lower rate. Furthermore, gender has an impact on the willingness to save. There is higher degree of risk aversion among women.

As expected marital status of all the income groups are estimated to have inverse affect on savings (Rehman et al., 2010). Usually it is seen that married households are less capable to save more amount as they were saving before marriage. Possible reason may be the fulfillment of responsibilities of the spouse. After marriage, there will be rise in family expenditure and they have to do more struggle for family survival.

A study by Browning and Lusardi (1996) study states that three factors were found to be determinants of the saving behavior of households in Africa. One of these was the ability to save which in turn depends on a household's disposable income and expenditure. The second was the propensity or willingness to save as influenced by socio cultural and economic factors like the family obligation to educate children. The third one was the opportunity to save and returns on savings.

As A. Samantaray and S. K. Patra (2014), a study conducted shows that variableslike income, age dependency, interest rate and inflation have significant impact on household savings in the long run. It may be interpreted that in the long run, increase in household savings, while increase in age dependency, raises household savings. Similarly increase in interest rate increases savings and inflation reduces household savings.

The study done by Birhane Melese (2015) showed that annual expenditure had statistically significant and positive effect on rural households' savings status in the study area. This implies that as income of the sampled households' increases, their expenditures increases in some amount similarly their saving also increases. The finding was similar with the work of Rehman et al.(2010) that shows positive relationship between expenditure and rural household saving.

According to Gedela (2012), the study results show the age of the head of the household, sex, dependency ratio, income and medical expenditure are significantly influencing the saving behavior in the entire study area. In the tribal area, dependency ratio and medical expenditure has severely affected of household savings. Income is the most crucial factor of the saving behavior in the entire study. The study found that male headed households save more than female headed households.

According to H. S. Nuhu et al (2015), the study concluded that there was high percent of savers and few non savers among the women in the area. The women preferred the use of informal saving mobilization type than formal savings mobilization types. This was because the informal saving mobilization type was more accessible to them than the formal. ROSCAs were the most preferred informal saving mobilization, followed by the daily contribution scheme. Income, education, marital status, working experience and type of saving institution used by respondents was found to influence their likelihood of saving.

A study by Browning and Lusardi (1996) study states that three factors were found to be determinants of the saving behavior of households in Africa. One of these was the ability to save which in turn depends on a household's disposable income and expenditure. The second was the propensity or willingness to save as influenced by socio cultural and economic factors like the family obligation to educate children. The third one was the opportunity to save and returns on savings.

As studied by K.S. Tesfamariam (2012), it was found from the results of variables such as family size, age, distance to RUSACCO, education, and expenditure are statistically significant and negatively related to the amount of savings mobilized in the study area. On the other hand interest rate, loan repayment and training were found to be insignificant in explaining saving mobilization and were ignored.

A study conducted by Girma et al. (2014) identified determinants of rural households' savings in East 
Hararghe Zone, Oromia Regional State, Ethiopia. Nine significant determinant explanatory variables of rural households savings were identified which includes household head's education level, livestock holdings, access to credit service, income, investment, training participation, contact with extension, forms of savings and saving motives.

\section{VARIABLE IDENTIFICATION \\ Gender}

The gender of the members could also be an important factor in the saving behaviour of the household. The gender also determines the income level of the earning member of the family. It can also affect access to other resources which could influence the income and well-being of the family.

H1: Gender of the member has significant relationship with household participation on small savings

Age

Age is expected to be an important factor which influences the saving capacity of a family. Older people save less a compared to younger people. Young people who earn less or little or no income will have less amount to save. So the relationship between age and saving behaviour is non-linear.

H2: Age of the member has significant relationship with household participation on small savings Income of the family

Total household income refers to the sum total of the earnings of the household in a year from farm and off-farm sources. The income is expected to boost household's food production by increasing access to more productive resources (Kifle, 2012).

H3: Income of the member has significant relationship with household participation on small savings

Marital Status of Head

Marital Status of household head is also an important factor that has very significant effect on household savings. When household head is un-married, he has no responsibility regarding family. He has less expenditures and more money to save for future needs. But after marriage, he has to look after his family, children, relatives, and have more domestic expenditures than past. Theoretically, household saving is expected to be negatively affected by Marital Status.

H4: Marital status of the member has significant relationship with household participation on small savings Expenditure of the family

It is a continuous variable which is measured in Birr. It affects rural households saving negatively. The more the households spend, their saving reduces. Rehman et al. (2010) indicated that expenditure significantly and inversely affecting household saving. The expected effect of expenditure on rural household saving was negative. H5: Expenditure of the family has significant relationship with household participation on small savings Family Size

The family size of the household is the total number of members in a family which includes spouse, children etc. The more number of family members increases then the family expenditure also increases which leads to lesser saving capacity of the household. A small family will be in a better position to save more as it will have lesser expenditure.

H6: Family size of the member has significant relationship with household participation on small savings Educational Status

In Ethiopia saving and credit cooperatives initially emerged through some scholars and urban employees. Sample members' education status helps them not only to understand how to make money but also to prudently and profitably handle cash in financial institutions, which are found in nearby areas.

H7: Educational status of the member has significant relationship with household participation on small savings

\section{RESEARCH METHODOLOGY}

The study has been conducted on the basis of the primary data collected through structured questionnaire. As the approach aims at analysing the influence of demographic factor on the small savings habits of the household, the research design has been taken to be causal. The study was undertaken between Jan 2018 - June 2018. The study was carried out at Wolaita Sodo Town. The data was collected from 385 household who participate in the small savings at $95 \%$ confidence level. Judgemental sampling technique was used to choose the respondents. A survey questionnaire was prepared using five point Likert scale $(1=$ strongly disagree, $5=$ strongly agree $)$ to measure the response on continuous scale. Descriptive and inferential statistics were used as data analysis tool. Reliability of the instrument was checked through Pilot study. The calculated reliability Cronbach's alpha was 0.839 which shows that questionnaire is highly reliable.

\section{DATA ANALYSIS AND INTERPRETATION}

The study is carried out at Wolaita Sodo town, Ethiopia. The data was collected from 385 households. So the results are based on 385 questionnaires of sample determination at $95 \%$ confidence level. 
Table 1 shows the analysis of variance of household participation on small savings based on gender. The result of analysis states that there is statistically insignificant difference of household participation on small savings based on respondent's gender since its $\mathrm{P}$ value is 0.194 which is $>.05$.

Table 2 shows the analysis of variance of household participation on small savings based on Age. The result of analysis states that there is statistically significant difference of household participation on small savings based on respondent's Age since its $\mathrm{P}$ value is 0.011 which is $<.05$.

Table 3 shows the analysis of variance of household participation on small savings based on Income factor. The result of analysis states that there is statistically significant difference of household participation on small savings based on respondent's Income factor since its $\mathrm{P}$ value is 0.000 which is $<.05$.

Table 4 shows the analysis of variance of household participation on small savings based on marital status. The result of analysis states that there is statistically insignificant difference of household participation on small savings based on respondent's marital status since its $\mathrm{P}$ value is 0.338 which is $>.05$.

Table 5 shows the analysis of variance of household participation on small savings based on level of expenditure. The result of analysis states that there is statistically significant difference of household participation on small savings based on respondent's level of expenditure since its $\mathrm{P}$ value is 0.013 which is $<.05$.

Table 6 shows the analysis of variance of household participation on small savings based on family size. The result of analysis states that there is statistically significant difference of household participation on small savings based on respondent's family size since its $\mathrm{P}$ value is 0.000 which is $<.05$.

Table 7 shows the analysis of variance of household participation on small savings based on educational status. The result of analysis states that there is statistically insignificant difference of household participation on small savings based on educational status since its $\mathrm{P}$ value is 0.217 which is $>.05$.

\section{CONCLUSION AND RECOMMENDATIONS}

The analysis of variance of demographic variables on household participation on small savings showed that gender, marital status and educational status were statistically insignificant to predict the household participation on small savings whereas Age, expenditure factor, level of income and family size were statistically significant to predict household participation on small savings. Growing economy in developing countries like Ethiopia needs well-established financial institution in rural parts of Ethiopia to provide financial services for the purpose of stimulating development. Small savings provides credit services in rural areas in order to encourage saving. Therefore, measures should be taken in improving saving behavior of members in line with the use of credit. Deposit interest rate results in increment in saving. So the operators of small saving schemes should have to improve the quality of rendering service relating to deposit interest rate. Integrating with stakeholders and nongovernmental organizations to bring behavioral change for use of saving accompanied by many ways through training, advancing systems technologically, improving services and promoting. Moreover, policy interventions should center on increasing awareness creation to inspire members saving. Generally, these factors affect members' saving behavior, therefore emphasis have to be given in designing strategies for awareness creation to bring change in members' saving behavior in the study area. As a result, members saving behaviour can be improved when they have awareness on saving service.

\section{SCOPE FOR FUTURE RESEARCH}

The factors remained unsolved by the model are large enough to conduct further study in the area. The other independent factors comprise training, financial literacy, timelines of credit, dependency ratio, distance and so on. Researches might consider saving behavior as dependent variable and can go for further study on the independent factors for interdependence of variables so that a depth understanding of the variables can be achieved and that it help to clearly identify more factors influence among variables in this study if exist.

\section{REFERENCES}

Attanasio (1997). Consumption and Saving Behavior: Modeling Recent Trends Fiscal Studies, Vol. 18, No.1 2347.

Kifle. (2012). Determinants of saving Behaviour of cooperative Members:An MSC thesis presented to School of graduate studies in Mekelle University, Mekelle.

Teka. (2008). Members' Savings Behavior and Determinants of Savings in Rural Savings and Credit Cooperatives. An MSC. thesis presented to School of Graduate Studies: Mdekelle University, Mekelle.

Fernandez, S. O. (2009). Determinants of the Europeans' retirement savings, Working Paper: De Compostela, University of Santiago.

Browning M., L. A. (1996). Household saving: micro theories and micro facts. Joural of Economics Literature, 45.

Rehman Hafeez, F. M. (2010). Households Saving Behaviour in Pakistan: A Case of Multan District, No. 1, pp. 17-29. Pakistan Journal of Social Sciences (PJSS), Vol. 30. 
Gedela, S. (2012). Determinants of Saving Behavior in Rural and Tribal Households: An Empirical Analysis of Visakhapatnam District. International Journal of Research in Social Sciences, 2(8).

Nuhu, H. S. (2015). Determinants of savings among rural women. Department of agricultural extension services, university of maiduguri, borno state, nigeria. Asian journal of agricultural extension .

Patra, A. S. (2014). Determinants of household saving in India, Kalapet: Department of Economics, Pondicherry University, Pondicherry 605014, India.

Tesfamariam, K. (2012). Saving behaviour and determinants of saving mobilization by rural financial cooperators. An MSC. thesis presented to school of graduate studies:Mekelle University, Ethiopia.

Browning M., L. A. (1996). Household saving: micro theories and micro facts. Journal of Economics Literature, 45.

Girma Teshome, B. K. (2014). Saving patterns of rural households in East Hararghe: Journal of Development and Development Economics, 6(4):177-183.

Melese, B. (2015). Factors affecting rural households savings: The case of Gedeb Hasasa District, West Arsi Zone of Oromia, Ethiopia. Haramaya University, Haramay, 37.

Salole, G.1986. Equb, Iddir and Meredaja Mahiber as potential development tool in Addis Ababa. In: Symposium on the centenary of Addis Ababa, 24-25 November, Addis Ababa. Addis Ababa: Addis Ababa University IES.

TABLES AND FIGURES

FIG 1: CONCEPTUAL FRAMEWORK OF THE STUDY

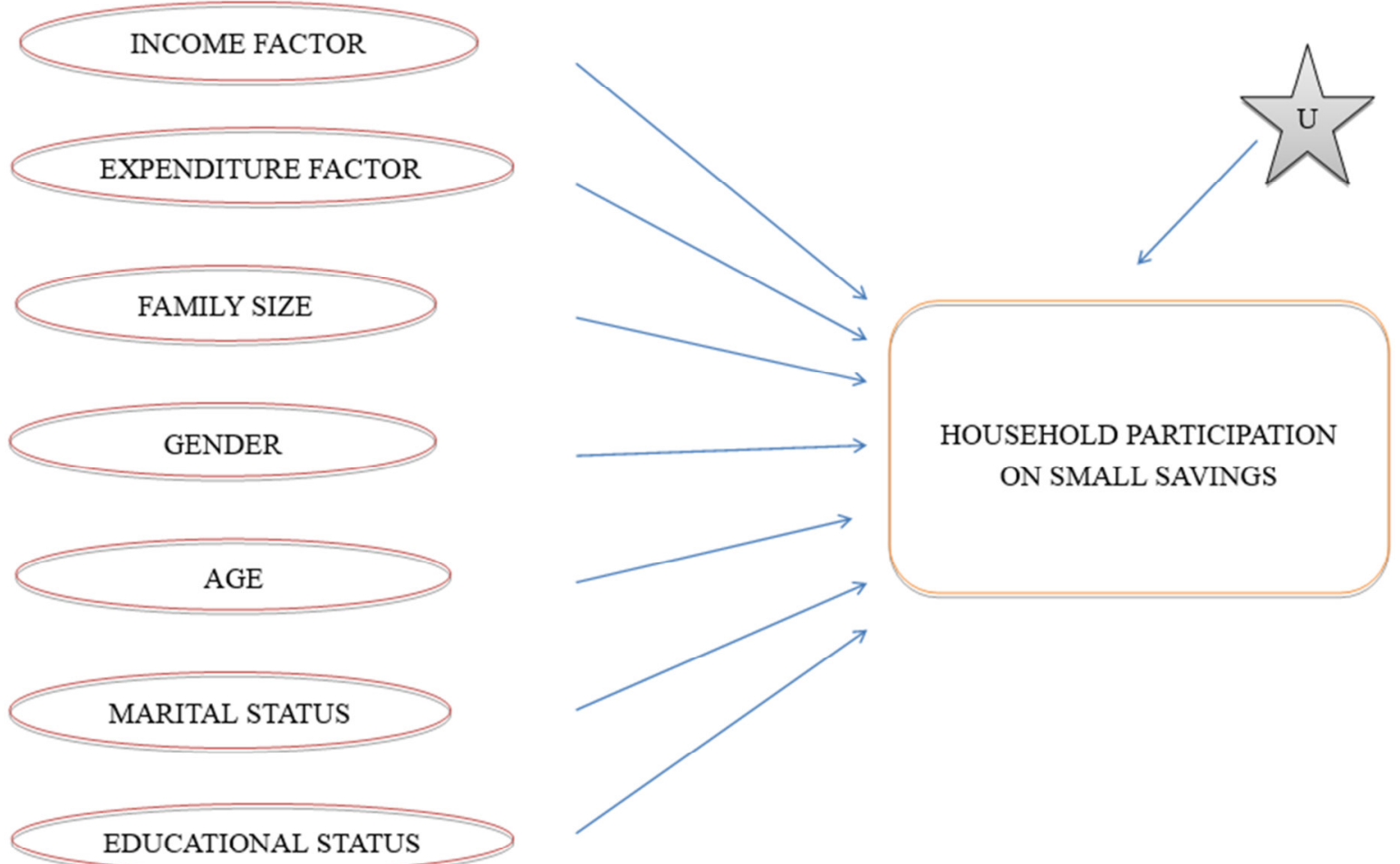

INDEPENDENTVARIABLES

DEPENDENT VARIABLE

Table 1: Analysis of Variance of Gender on household participation on small savings

\begin{tabular}{|l|c|c|c|c|c|}
\hline & Sum of Squares & Df & Mean Square & F & Sig. \\
\hline Between Groups & 2.003 & 1 & 2.003 & 1.690 & .194 \\
\hline Within Groups & 453.879 & 383 & 1.185 & & \\
\hline Total & 455.882 & 384 & & & \\
\hline
\end{tabular}

Table 2: Analysis of Variance of Age on household participation on small savings

\begin{tabular}{|l|c|c|c|c|c|}
\hline & Sum of Squares & Df & Mean Square & F & Sig. \\
\hline Between Groups & 15.260 & 4 & 3.815 & 3.290 & .011 \\
\hline Within Groups & 440.622 & 380 & 1.160 & & \\
\hline Total & 455.882 & 384 & & & \\
\hline
\end{tabular}


Table 3: Analysis of Variance of Income factor on household participation on small savings

\begin{tabular}{|l|c|c|c|c|c|}
\hline & Sum of Squares & Df & Mean Square & F & Sig. \\
\hline Between Groups & 27.907 & 2 & 13.953 & 12.454 & .000 \\
\hline Within Groups & 427.975 & 382 & 1.120 & & \\
\hline Total & 455.882 & 384 & & & \\
\hline
\end{tabular}

Table 4: Analysis of Variance of marital status on household participation on small savings

\begin{tabular}{|l|c|c|c|c|c|}
\hline & Sum of Squares & Df & Mean Square & F & Sig. \\
\hline Between Groups & 2.584 & 2 & 1.292 & 1.089 & .338 \\
\hline Within Groups & 453.297 & 382 & 1.187 & & \\
\hline Total & 455.882 & 384 & & & \\
\hline
\end{tabular}

Table 5: Analysis of Variance of expenditure factor on household participation on small savings

\begin{tabular}{|l|c|c|c|c|c|}
\hline & Sum of Squares & Df & Mean Square & F & Sig. \\
\hline Between Groups & 18.924 & 6 & 3.154 & 2.728 & .013 \\
\hline Within Groups & 436.958 & 378 & 1.156 & & \\
\hline Total & 455.882 & 384 & & & \\
\hline
\end{tabular}

Table 6: Analysis of variance of family size on household participation on small savings

\begin{tabular}{|l|r|r|r|r|r|}
\hline & \multicolumn{1}{c|}{ Sum of Squares } & \multicolumn{1}{c|}{ Df } & Mean Square & \multicolumn{1}{c|}{ F } & Sig. \\
\hline Between Groups & 34.905 & 4 & 8.726 & 7.877 & .000 \\
\hline Within Groups & 420.976 & 380 & 1.108 & & \\
\hline Total & 455.882 & 384 & & & \\
\hline
\end{tabular}

Table 7: Analysis of Variance of educational status on household participation on small savings

\begin{tabular}{|l|r|r|r|r|r|}
\hline & \multicolumn{1}{|c|}{ Sum of Squares } & \multicolumn{1}{c|}{ Mean Square } & \multicolumn{1}{c|}{ F } & Sig. \\
\hline Between Groups & 4.962 & 4 & 1.240 & 1.455 & .217 \\
\hline Within Groups & 450.92 & 380 & 1.186 & & \\
\hline Total & 455.882 & 384 & & & \\
\hline
\end{tabular}

Table 8: Hypothesis testing

\begin{tabular}{|l|l|l|l|}
\hline No & Hypothesis & P-Value & Accept/ Reject \\
\hline $\mathbf{H}_{\mathbf{1}}$ & $\begin{array}{l}\text { Gender of the member has significant relationship with } \\
\text { household participation on small savings }\end{array}$ & $.194>0.05$ & Rejected \\
\hline $\mathbf{H}_{\mathbf{2}}$ & $\begin{array}{l}\text { Age of the member has significant relationship with } \\
\text { household participation on small savings }\end{array}$ & $.011<0.05$ & Accepted \\
\hline $\mathbf{H}_{\mathbf{3}}$ & $\begin{array}{l}\text { Income of the member has significant relationship with } \\
\text { household participation on small savings }\end{array}$ & $.000<0.05$ & Accepted \\
\hline $\mathbf{H}_{\mathbf{4}}$ & $\begin{array}{l}\text { Marital status of the member has significant relationship } \\
\text { with household participation on small savings }\end{array}$ & $.338>0.05$ & Rejected \\
\hline $\mathbf{H}_{\mathbf{5}}$ & $\begin{array}{l}\text { Expenditure of the family has significant relationship with } \\
\text { household participation on small savings }\end{array}$ & $.013<0.05$ & Accepted \\
\hline $\mathbf{H}_{\mathbf{6}}$ & $\begin{array}{l}\text { Family size of the member has significant relationship } \\
\text { with household participation on small savings }\end{array}$ & $.000<0.05$ & Accepted \\
\hline $\mathbf{H}_{7}$ & $\begin{array}{l}\text { Educational status of the member has significant } \\
\text { relationship with household participation on small savings }\end{array}$ & $.217>0.05$ & Rejected \\
\hline
\end{tabular}

